\title{
From Early Trade and Communication Networks to the Internet, the Internet of Things and the Global Intelligent Machine (GIM)
}

\author{
Teun Koetsier \\ Department of Mathematics, Faculty of Science, VU University, Amsterdam, The Netherlands \\ Email: t.koetsier@vu.nl
}

How to cite this paper: Koetsier, $\mathrm{T}$. (2019). From Early Trade and Communication Networks to the Internet, the Internet of Things and the Global Intelligent Machine (GIM). Advances in Historical Studies, 8, 1-23.

https://doi.org/10.4236/ahs.2019.81001

Received: December 21, 2018

Accepted: January 29, 2019

Published: February 1, 2019

Copyright $\odot 2019$ by author(s) and Scientific Research Publishing Inc. This work is licensed under the Creative Commons Attribution International License (CC BY 4.0).

http://creativecommons.org/licenses/by/4.0/

\begin{abstract}
The present paper offers a sketch of the history of networks from the Stone Age until the present. I argue that man is a creator of networks, a homo reticulorum. Over the course of time more and more networks were created and they have become increasingly technologized. It seems inevitable that they will all be incorporated in the successor of the Internet of Things, the Global Intelligent Machine (GIM).
\end{abstract}

\section{Keywords}

History of Networks, Global Intelligent Machine

\section{Introduction}

Although we nowadays also use the word tool in a more general sense, tools and machines are traditionally physical devices invented to perform a task. They have a material existence and they operate on the basis of the laws of physics. When a tool gets more complex it is called a machine. We will not make a precise distinction between tools and machines. Production and information tools and machines represent two essential aspects of human nature. Human beings physically intervene in nature, on the one hand, and they process information, on the other hand. Making things is an expression of the first aspect: we are a homo faber. Talking is an expression of the second aspect: we are also a homo loquens. In The Ascent of GIM, the Global Intelligent Machine I studied the history of the two kinds of tools and machines from the Stone Age until the present (Koetsier, 2019). The first production and information tools were invented in the Stone Age. In the Agricultural empires production and information tools and machinery gradually became more complex. During and after the 
Industrial Revolution in the 18th century the pace of innovation accelerated. In the 20th century the mechanization of production and information processing became increasingly sophisticated. Robots appeared. They are hybrid machines, combinations of a production machine and a computer. In the last decades of the $20^{\text {th }}$ century a new kind of information machine was introduced, the Internet. The Internet has now been connected to billions of sensors and has become the Internet of Things (IoT). The next step is that the IoT becomes what I call GIM, the Global Intelligent Machine. The IoT will be connected to more and more production machinery and will become a huge intelligent global machine that not only collects, stores, and processes information but also physically intervenes in the world. The result is GIM, a huge global robotic machine, a combination of production machinery and information machinery. In the future it may very well encompass all machinery on the globe.

The core of GIM is the Internet, a global information network. The Internet and GIM are also expressions of a third aspect of our species that deserves attention, next to the fact that we are creatures that physically interact with nature and process information. We create networks. We are not only a homo faber and a homo loquens, but a homo reticulorum as well, a creator of networks. In general a network consists of nodes and connections between them. The nodes can be many things, for example, individuals, computers or locations in space. The connections are all possible lines of communication or transfer of individuals or goods. Usually networks look somewhat like fishing nets, but we will also include borderline cases without branches, that look like a rope with a few knots in it.

Traditionally the application of production tools and machines is called mechanization. I will use the word technologization to cover both the application of production and information tools and machines. This paper considers the rise of GIM from the point of view of the history of the technologization of networks. The technologization can concern all aspects of a network: the nodes, the connections, the means of transportation and the loads that are transported.

The etymological online dictionary (https://www.etymonline.com) says that a network was originally (1550s) a net-like arrangement of wires. Only after 1839 the word started to be used for transportation networks in reference to rivers, roads and rails. The meaning broadcasting system is from 1914 and after 1947 it started to mean also an interconnected group of people. There are many studies on the history of transportation, radio and television, but I have not been able to find any historical study of networks in general. The present paper seems to fill a gap.

\section{Early Networks, the Movement of Goods and People}

The early hunters and gatherers lived in small groups in Africa, forming their small mobile communication and transportation networks of which the group members were the nodes. At a certain moment these groups became parts of bigger networks in which the groups were connected by trade relations. This 
may have started as early as 200,000 years ago. According to Nick Blegen "Long-distance transport of high quality raw materials and the increases in hominin behavioral intergroup interactions that this behavior entails were important parts of the hominin repertoire in East Africa [circa 200,000 years ago], at or before the time H. sapiens first appears in the region" (Blegen, 2017). Blegen analyzed obsidian found at the Sibilo School Road Site in Kenya and discovered that most of the obsidian came from a source $166 \mathrm{~km}$ south of the site. Obsidian is a volcanic glass that can be fractured to produce sharp blades or arrowheads. Because it is not perishable and usually can be mined only at specific locations, it is a good indication of long distance trade. Interactions between groups operating in different areas led to trade and the further development of technology inevitable led to growing variation in traded goods. Find-spots of Upper-Paleolithic Venus figurines are located over an area from Siberia to Western Europe. The Venus of Hohle Fels is an early one dated between 35,000 and 40,000 years ago. It is highly probable that this "form of art" was invented at one particular spot and then spread via trade networks.

Intensive trade did not have to wait for the appearance of the great agricultural societies. In 1983 Bryant Allen wrote "Before white contact Papua New Guinea communities were small and very localized. [...] Travel was discouraged by rugged terrain and hostile neighbors. Nevertheless, the country was criss-crossed with well-established trade routes along which travelled food, animal products, bird plumes, dogs' teeth, sea shells, fish, clay pots, potassium and sodium salt, sago, stone axe blades, obsidian, wicker baskets, wooden dishes, string bags, paints, dyes and coloured earths, as well as art forms, dances, magic, sorcery and new ideas" (Allen, 1983). Within all areas intensive local trade occurred. This means that the communities were indirectly linked. The quotation shows a great variety of goods and it reflects the situation after the invention of agriculture and the domestication of animals. An early written reference to this type of trade in which the goods changed hands repeatedly, is found in Herodotus. He wrote in the 5th century BCE: “They [the Delians] say that offerings wrapped in straw are brought from the Hyperboreans to Scythia; when these have passed Scythia, each nation in turn receives them from its neighbors until they are carried to the Adriatic sea, which is the most westerly limit of their journey; from there, they are brought on to the south, the people of Dodona being the first Greeks to receive them. From Dodona they come down to the Melian gulf, and are carried across to Euboea, and one city sends them on to another until they come to Carystus; after this, Andros is left out of their journey, for Carystians carry them to Tenos, and Tenians to Delos" (Herodotus, 1920, 4.33). Hyperborea was for the Greeks a mythical country in the North. The quotation indicates the existence of a trade route linking the Baltic with the Aegean. Seltman has argued that Herodotus' description should not be taken to literally (Seltman, 1928). Yet that does not diminish its value as a description of how trade took place.

The growth of the trading networks went hand in hand with the introduction 
of new technologies. Baskets, ropes and other means to make the transportation of goods easier appeared very early indeed.

\section{Boats, Wagons and the Domestication of Beasts of Burden}

Trade routes over land go back far, but so do maritime trade routes. Around 60,000 years ago the first humans to settle New Guinea and Australia came from the Indonesian islands and must have used boats. The boats in general will have been used locally, but not later than the time of the rise of the agricultural empires trade intensified. Indian traders from the Indus valley were active in $\mathrm{Me}$ sopotamia in the 3rd millennium BCE (Gosch \& Stearns, 2008). That means they traveled more than $2000 \mathrm{~km}$ along the coast. Sails were invented much earlier, According to R. A. Carter, in de 5th millennium BCE the Mesopotamians had boats with masts, which is strong evidence for the existence of sails (Carter, 2012). There were also contacts and exchange between Mesopotamia and the Egyptian civilization in the Nile Valley. This led in the 3rd millennium BCE to the establishment of a vast zone of long distance interchange in the Nile-Indus region (Gosch \& Stearns, 2008: p. 9). This points also at the development of the art of coastal navigation. Obviously inside Egypt and Mesopotamia the rivers were an essential part of the trade network (see Figure 1).

It is often thought but not certain that the wheel was invented in Mesopotamia. A decorated clay mug from the Trechterbecher culture dated about 3500-3350 BCE, was found in Bronocice in Poland. It depicts a wagon, a harness pole, and a yoke. Three dimensional ceramic models have been found from the same period, for example, from the Baden culture. This culture appeared in Hungary about 3500 BCE. After the domestication of the cow, oxen-usually castrated bulls-could be used to pull a wagon. The invention spread very quickly.

Evidence for wheeled vehicles is widespread after 3500 BCE. On clay tablets found in the remains of the Eana temple in Uruk, dating from the 4th millennium BCE, we find a pictograph showing a four wheeled wagon with some kind of superstructure. Basalla assumes that in Mesopotamia the earliest wagons were

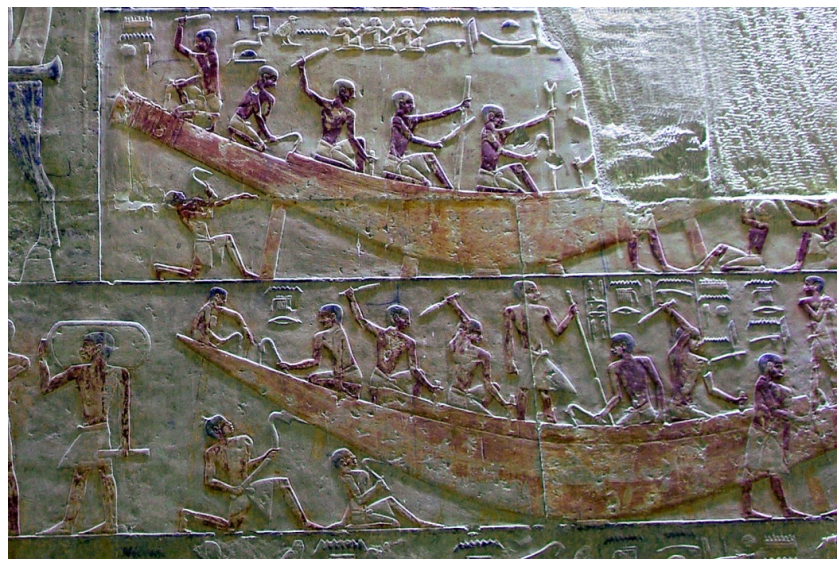

Figure 1. Shipbuilding in ancient Egypt. Scene from the tomb of Ti (official under pharaoh Neferirkare Kakai of the 5th dynasty). Picture retouched by Berthold Werner. 
used to transport statues of gods or important persons. He supposes that they were used for ceremonial purposes and rituals. Soon however, they were used by the military (see Figure 2).

On the same tablets the sign for sledge occurred much more often. Sledges must have been used far more often in Uruk at the time. They existed before the invention of the wheel not only in Mesopotamia but in Eastern Europe as well, in the form of bent-wood sledges.

The domestication of beasts of burden was important as well. The domestication of horses probably took place in the 4th millennium BCE in the Eurasian Steppe Belt. The domesticated horse seems to have reached China and Mesopotamia after 2000 BCE. According to Martin Heide the Bactrian camel was probably domesticated before the dromedary and was put into use by the middle of the 3rd millennium or earlier. The camel soon reached the Mesopotamian civilization but only in the 2nd millennium it was used frequently there (Heide, 2010: p. 367). The Silk Road became only viable after the camel was domesticated. Camels can walk long periods of time without an external source of water. The connection between China and Rome was made during the Han dynasty (207 BCE-220 CE), but at the time the Romans had no clear idea of the origin of the silk. The Periplus of the Erythraean Sea from probably the 1st century CE seems to be the first document in which a "city called Tina" (=China) is mentioned from which the silk floss originated. For a long time long distance trade by land took place indirectly via many middlemen. Travelling in unknown lands was risky.

\section{Roads and Water Networks}

Maps of some sort will have played a role in coastal navigation. In the third or second millennium BCE, the Polynesians spread through the islands of Southeast Asia. They started out from Taiwan and in the end reached Easter Island. The Polynesians used different methods to memorize the positions of the many island groups, for example by means of maps made out of sticks tied together in which the pebbles indicated islands. In Mesopotamia plans of temples go back to the 3rd millennium and circa 1500 BCE a map of the city of Nippur was drawn

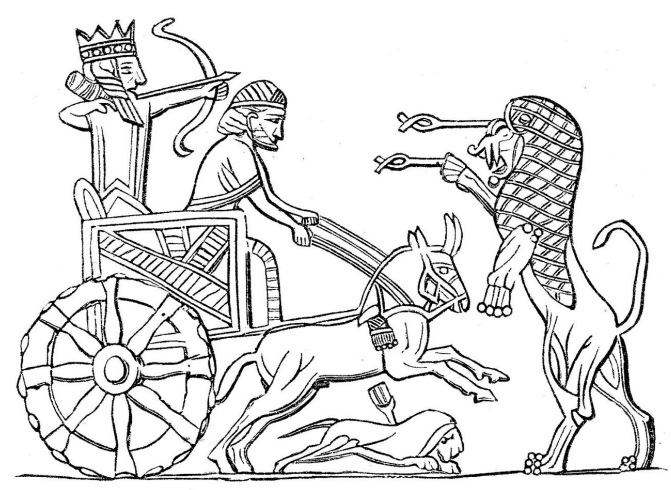

Figure 2. War chariot, from an Achaemenid seal impression. 
to scale (Millard, 1987). Mapmaking is related to the invention of writing. Writing was independently invented in the early agrarian societies in Mesopotamia, Egypt, China, and Meso-America. Trade networks also transported messages. With writing it became possible to transmit information reliably across time and space, hardly without boundaries. The climax of the development was the invention of the alphabet: a small set of characters, easy to learn, suitable to represent in principle every spoken word. It was ideal for traders and probably not accidentally invented by Phoenicians and Greeks.

Communication networks existed in all centralized agricultural societies. In the first millennium BCE we see a new element: a material infrastructure is consciously created to facilitate communication and transportation. In the 5th century BCE the Royal Road of the Persian Empire ran from the city of Susa to Smyrna on the Aegean Sea. It was nearly $3000 \mathrm{~km}$ long. Rivers were crossed by ferry. Herodotus described it in his Histories: “All along it are the king's road stations and very good resting places, and the whole of it passes through country that is inhabited and safe" (Herodotus, 1920, 5.52). Couriers on horseback could travel the Royal Road in 7 days.

These systems of roads are early material networks. Other material networks are irrigation systems. The earliest systems of irrigation seem to have been built in the Indus valley and in Mesopotamia and Egypt. In Mesopotamia water storage systems, canals and ditches were dug and gates were built to control the flow.

Assurnasipal II (884-859 BCE), the Assyrian king had a canal dug $19.5 \mathrm{~km}$ long. It passed under a rock ridge via a tunnel $7 \mathrm{~km}$ long. The tunnel was built using the shafts-and-gallery tunnel technique. The shafts were built at sufficiently close distances so that on the surface the course of the tunnel could be controlled. The tunnel led to the city of Nimrod which it supplied with water and where it irrigated fields (Wilson, 2008: p. 290). A very important long-distance water supply technology was the qanat (see Figure 4). A qanat is an aqueduct tunnel built by means of the shafts-and-gallery technique that gets its water from a location where the level of the ground water is higher than where the water is needed. This may require shafts of considerable depth. Qanats dating from the 1st millennium are found in Iran, in Egypt and in the Arabian Peninsula.

It is interesting that a public water supply and a sewer network seem to have existed in the fortified city that existed at the archeological site Harappa in (now) Pakistan in the 3rd millennium BCE.

In course of time machines to lift water were designed. The shaduf is one of the earliest tools used to lift water (see Figure 3). It seems that the noria and the sakia do not appear before the last millennium BCE. The noria and the sakia are devices consisting of buckets attached to a wheel (see Figure 4 and Figure 5). The wheel of the sakia is traditionally set in motion by an animal (see Figure 5 and Figure 6). The animal makes a big gear wheel turn which drives a gear wheel on the axle of the water wheel. Gear wheels only appear in the second half of the 1st millennium BCE. Possibly the early sakias were driven by manpower. 


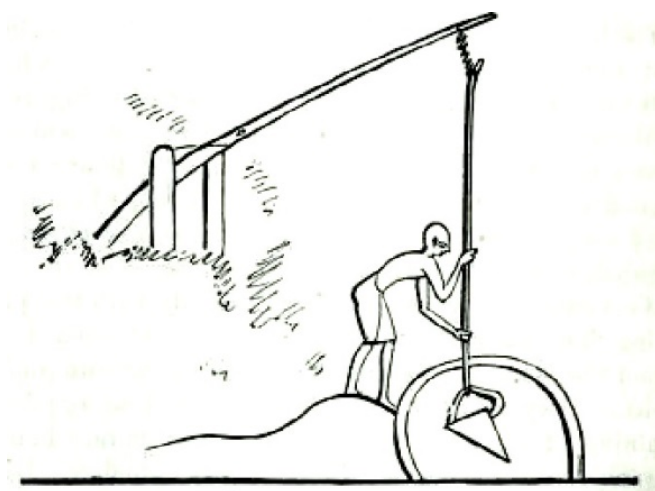

Figure 3. The shaduf: the short end of the lever carries a counterweight.

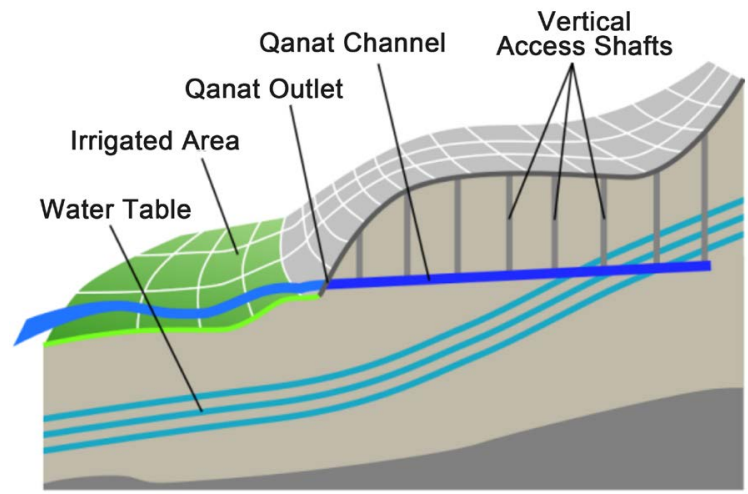

Figure 4. A qanat.

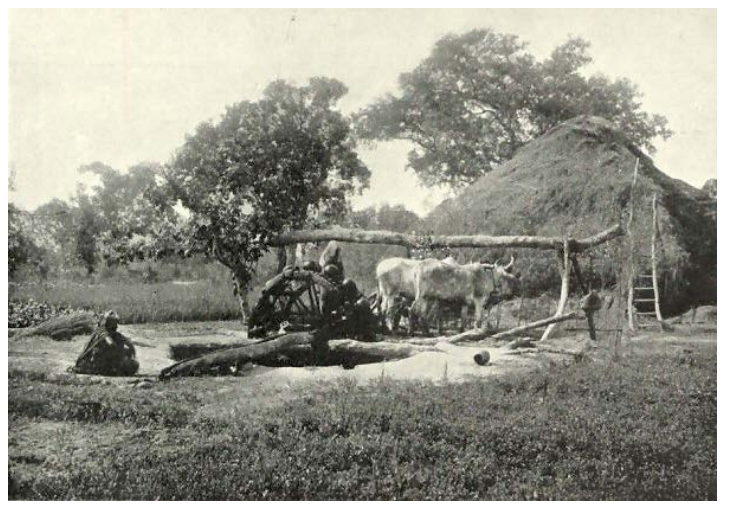

Figure 5. Sakia in Persia in 1905. Courtesy of Special Collections, University of Houston Libraries.

Stephanie Dalley has argued that the Archimedean screw-pump was already known during the reign of the Assyrian king Sennacherib (704-681 BCE) and that the pump was used to water the king's palace garden at Nineveh (see Figure 7). And although there is an Akkadian inscription in which Sennacherib (705-681 BCE) writes: "In order to draw water up all day long I had ropes, bronze wires and bronze chains made, and instead of shadufs I set up the great cylinders", the evidence that these great cylinders were screw pumps is not conclusive. Strabo wrote about the hanging gardens of Babylon: "The topmost story 


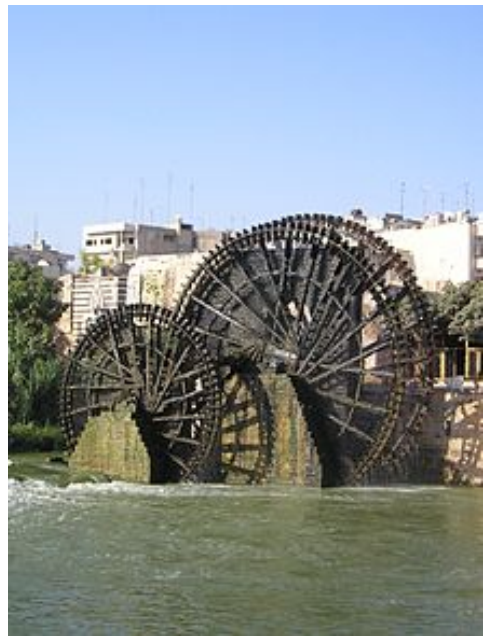

Figure 6. Norias in Syria. Such norias were driven by water power and were used to lift water into an aqueduct.

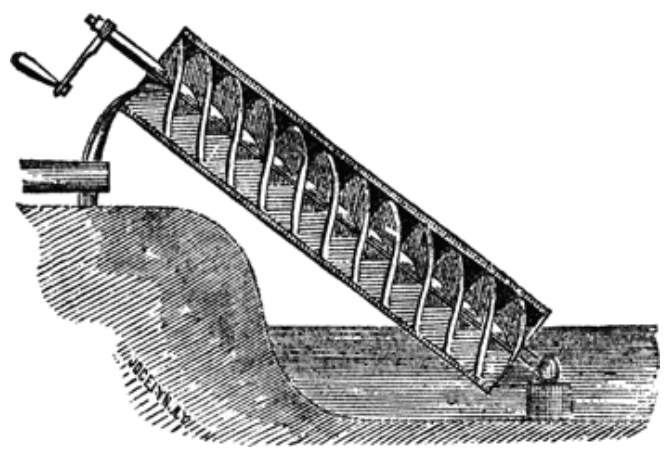

Figure 7. Archimedean screw-pump.

is approached by a stairway that has water screws [кох $\lambda$ iac] installed alongside, by means of which those assigned to the task used to raise water up continuously into the gardens from the Euphrates" (Dalley \& Oleson, 2003: p. 12). Strabo lived two centuries after Archimedes and Moschion attributes the invention of the screw pump to Archimedes. Concerning the Great Ship of Hiero of Syracuse he wrote: "And the bilge, although of a remarkable depth, was pumped out by a single man operating a water screw, an invention by Archimedes" (Oleson, 1984: p. 60). Remains of screw-pumps consisting of a single helicoid were found in Spanish copper-mines from the imperial period (Kellermann \& Treue, 1962: p. 23).

\section{The Greeks and the Romans}

The word "labyrinth" is Greek. It was the name of the structure that the famous Greek inventor Daedalus created on Crete for king Minos. We do not know what it looked like. Strictly speaking a labyrinth consists of pathways with twists and turns but no branches. Yet, it may have been a real maze, that is a network with branches.

According to Ober by the second quarter of the fourth century Athens put in- 
to place a fortification system meant to protect the whole of Attica (Ober, 1985). The idea was to stop or at least slow down the enemy while the main Athenian forces were alerted by means of signal transfers. Such a communication system with watch posts and signal relay stations is a network. Ober suggests that they may have used the following method for the transfer of messages. When a torch is raised sender and receiver both set a cork float on top of the water of two identical water clocks. Part of the clock is a vertical list of messages. When a pointer attached to the float reaches the right message the sender again raises a torch. The receiver then knows which message is transferred.

Aqueducts are also networks. A famous $2.5 \mathrm{~km}$ long aqueduct was built on Samos in the 6th century BCE. Eupalinos of Megara designed the $1 \mathrm{~km}$ long tunnel that was part of it. The shafts-and-gallery technique could not be applied because of the height of the hill, so Eupalinos must have applied a surveying technique from the opposite ends. More ambitious aqueducts were pioneered in the Hellenistic period by engineers in Rome and in Pergamon. A key invention was the inverted syphon. Water is conveyed in a closed pipe that follows the shape of a depression and exits at a level somewhat lower than the level of entrance (see Figure 8). The pipes were made of terracotta and later also of lead in order to withstand higher pressures (Wilson, 2008: p. 295). The Romans built many aqueducts. In particular with Emperor Augustus a real proliferation of the technology took place.

With the Roman Empire the West reached a very high level of civilization. Dionysius of Halicarnassus wrote in the 1st century BCE: "The extraordinary greatness of the Roman Empire manifests itself above all in three things: the aqueducts, the paved roads, and the construction of the drains" (Quilici, 2008: p. 552). The Royal Road of the Persians was not paved. The Romans introduced a completely new approach to the "networking of the landscape" (Quilici, 2008: p. 553). The primary goal was long-distance connections by means of a series of straight lines to keep the route as short as possible with little concern for the technical difficulties that this involved. This required geological evaluations, surveying techniques, excavations, drainage and bridge building. The first realization of the Via Appia built in 312 BCE was the connection between Rome and Capua, $196 \mathrm{~km}$. The paving was of polygonal basalt blocks. It was consistently 4.1 - $4.2 \mathrm{~m}$ wide. There was a gradient so that rainwater did flow to either side. There were milestones along the road. With the Via Appia as a model a considerable network of roads in ancient Italy was built and with the growth of the empire the network was extended outside of Italy. The roads made transportation of goods and people much easier, although the carriages were far from comfortable (see Figure 9).

In 1750 BCE Babylon seems to have been the biggest city in the world with 65,000 inhabitants (Morris, 2010: p. 116). A city of 65,000 inhabitants on a few square kilometers represents a considerable network of roads. However, in 100 CE Rome had a million inhabitants. Rome not only had a network of roads, but 


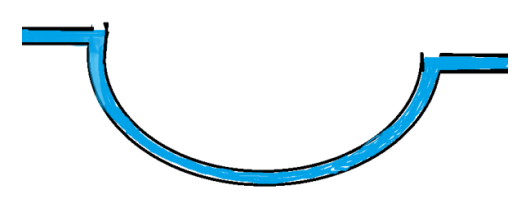

Figure 8. Inverted syphon.

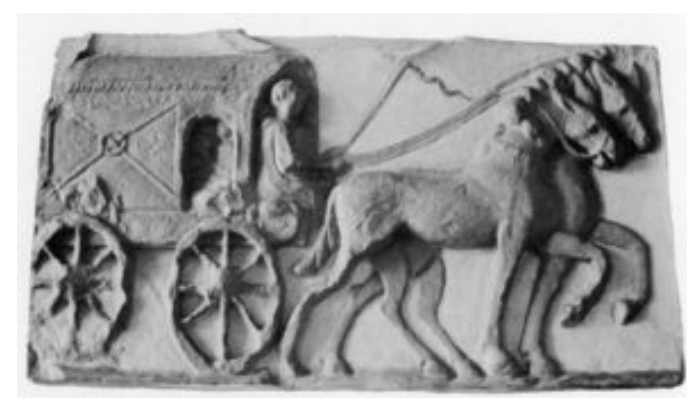

Figure 9. Roman carriage.

a covered sewer system, the Cloaca Maxima, and aqueducts that brought fresh water into the city. In the 3rd century CE Rome had 11 aqueducts (see Figure $10)$.

It is interesting that we know what the fresh water network in Pompeii looked like. Pompeii is on a relatively steep slope and the water was led downwards via 12 subsidiary distribution points with open tanks on towers. The open tanks and the towers reduced the pressure and yet maintained enough pressure to supply water to the upper stories of houses (Wilson, 2008: p. 303).

Emperor Augustus created the imperial message service, the Cursus publicus. It was used to transport messages and officials. At least until the 6th century the Byzantine Empire used it for the same purpose. At regular distances there were night quarters and fresh horses for the couriers. The average speed was $80 \mathrm{~km}$ per day (Eliot, 1955). In China under the Han Dynasty a similar postal relay system existed for "mail delivery, reconnaissance activities, and provision of chariots and rest-houses for traveling officials" (Edmund Lien, 2015).

There are various techniques for long distance communication. The military use of smoke, torches or drums to convey messages over long distances is very old. Apparently the signal towers of the Chinese Great Wall used codes to signal the size of the enemy: one fire and one cannon salvo up to 10 raiders, two fires and two cannon salvos for 500 to 1000 raiders, etc. (Lovell, 2007: p. 228). In the second century BCE Polybius describes in section 46 of Book 10 of his Histories a system to signal the letters of the alphabet by means of two numbers (see Figure 11). The sender raises, for example, 3 torches. The receiver knows now that he should look in the third row of the square. Then the sender raises, for example five torches. This means that the receiver should look in the fifth column. So it is the letter $\mathrm{P}$ that the sender meant to convey.

In classical antiquity we also find the use of homing pigeons. The results of the 


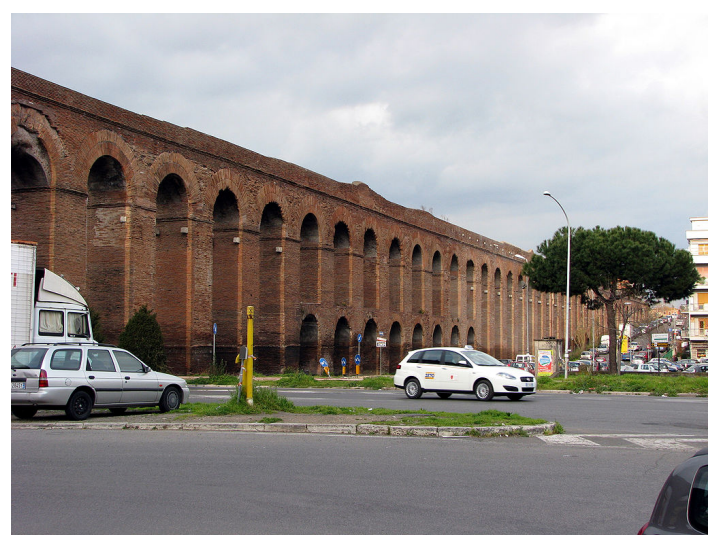

Figure 10. The Aqua Alexandrina, one of the aqueducts of Rome. The $22.4 \mathrm{~km}$ long aqueduct was in use from the 3 rd to the 8 th century CE.

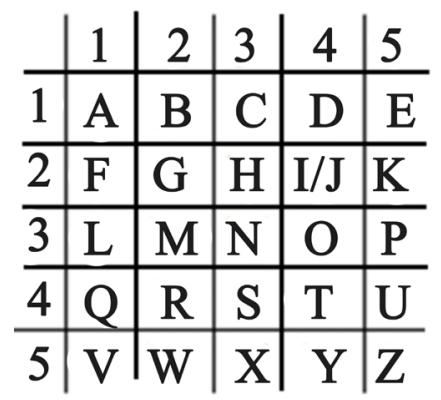

Figure 11. Polybius square (Based on the modern alphabet. The Roman alphabet differed slightly).

first Olympics in $776 \mathrm{BE}$ were delivered by a pigeon (Blechman, 2007: p. 4). Allegedly in the 6th century Cyrus the king of Persia used pigeons to communicate within his empire.

\section{The Industrial Revolution}

After the fall of the Western Roman Empire the development in the West not only stagnated, but many of the existing infrastructural networks deteriorated. In the East the situation was different. With the Song dynasty China reached a level of development comparable to the Roman Empire. When Marco Polo at the end of the 1270s visited Hangzhou, the capital of the Song, he saw an extremely rich city with more than a million inhabitants living in multistory wooden houses, with canals and thousands of stone bridges, densely populated and extremely well organized. Because the city was vulnerable to fire it was permanently observed from watch towers and by means of flags and light signals thousands of firemen could be directed quickly to the location of the fire.

Only in the 18th century with the Industrial Revolution in England the West would reach again a comparable level of development. Yet a lot happened in the meantime. In 1492 Columbus discovered America and in 1498 Vasco da Gama discovered the route to India via the Cape of Good Hope. Ferdinand Magellan crossed the Atlantic in 1521. He sailed along the coast of South-America, and 
went through what are now called the Straits of Magellan, crossed the Pacific and landed on the Philippines. Europe changed very much. Trade moved away from the Mediterranean to the Atlantic, the Indian Ocean and the far East. Spain, Portugal, England and Holland took the lead.

Without advances in shipbuilding and navigation the opening up of the new trade routes to America, India and China would not have been impossible. The compass came from China and was introduced at the end of the 12th century. It made it safer to navigate far beyond the sight of land. The sternpost rudder was introduced. The steering wheel came later. Multiple masts and multiple sails on one mast were introduced. Before the end of the 15th century the ship had almost reached the form it retained until the 19th century.

In about 1439 Johann Gutenberg of Mainz invented movable types in order to print text (see Figure 12). Soon distribution networks of print appeared. See (Meyers \& Harris, 1990) for a study of the distribution networks of print 1550-1850 in Britain.

Yet things really started changing with the Industrial Revolution. At the end of the 18th century newspapers were still printed on screw presses. In 1812 a fast steam powered press made its first trial run. This was built by two Germans, the inventor Friedrich Gottlob Koenig (1774-1733) and the watchmaker Andreas Friedrich Bauer (1783-1860). They further developed the press so that two sides of a page could be printed at the same time. The publisher of The Times bought the press and at the end of 1814 the first copies of that newspaper were printed on Koenig's press (see Figure 13).

The possibility to gasify coal or wood was discovered in the 18th century by William Murdoch. In 1807 Pall Mall in London became the first street with gas lighting. Soon gas lighting spreads to other cities and the continent. In England the Gas Light and Coke Company, the first company to supply London with gas, implemented a network of pipes for the distribution of gas. William Murdoch also invented the pneumatic mail. Sending mail in capsules through tubes by means of pressurized air became quite popular. In Paris a major network of tubes was used until 1984 (Hayhurst, 1974) (see Figure 14).

An early railway was completed in 1806 between Swansea and Oystermouth.

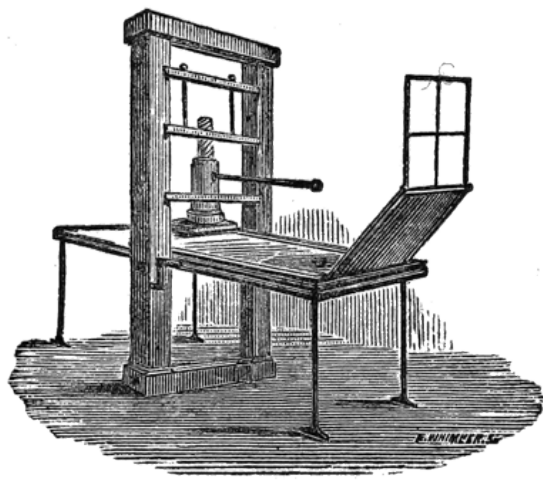

Figure 12. Early printing press. 


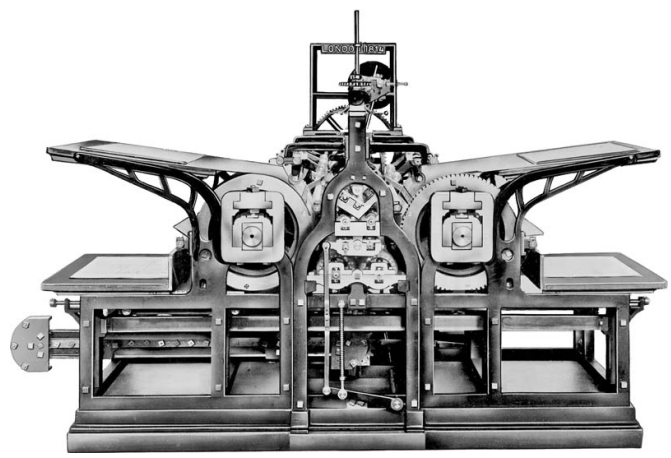

Figure 13. Koenig's 1814 steam-powered printing press.

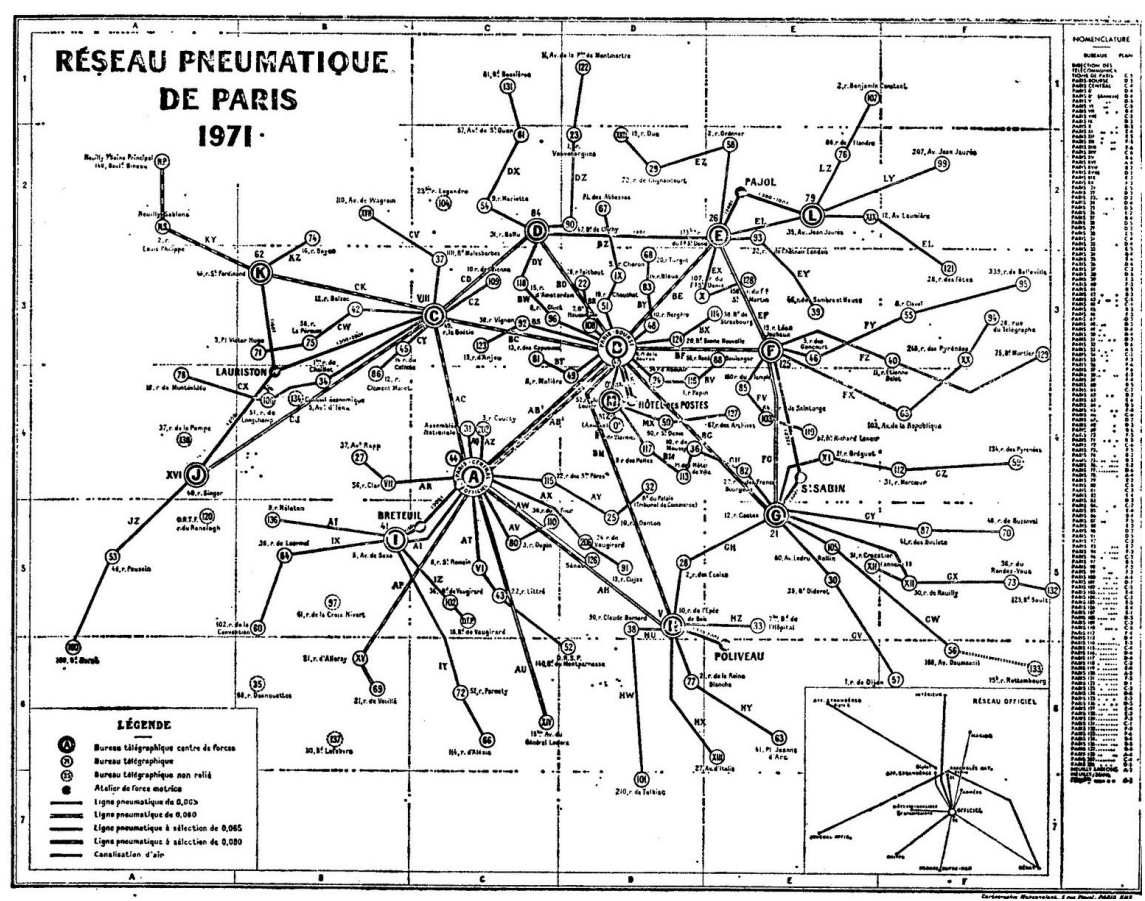

Figure 14. The pneumatic post of Paris. Courtesy of the France \& Colonies Philatelic Society.

Because Oystermouth was known as Mumbles, the railway was called the "Mumbles train". The train was pulled by horses. Only in 1877 the horses were replaced by steam. It took years but in the end the horse drawn trams became quite popular, in the UK, the USA and elsewhere.

Yet in 1851 the railroads and trains pulled by steam locomotives had become the dominating factor in the British economy. Over the course of time they replaced the canal track boats that were drawn by horses, and the coaches. The United Kingdom had a considerable network of inland waterways that was greatly improved in the 18th and the beginning of the 19th century. From the middle of the 19th century the railway began to replace the canal.

The first half of the 19th century is the period in which a large number of turnpike roads or toll roads were built in the UK. Although the framework of the main road system in Britain is the legacy of these turnpike roads, over the course 
of the 19th century many of the turnpike trusts lost the competition with the railroads and many saw them as an unnecessary barrier for free trade.

Horse drawn vehicles remained popular for a long time. At the end of the 19th century the horse drawn trams on rails started to be replaced by electric-powered streetcars. In a big city like New York horse drawn vehicles (not only trams) had become the main means of transportation for people and the hundreds of thousands of horses led to incredible pollution: urine, manure and dead horses.

In 1804 Trevithick ran the first steam locomotive in South Wales. Four years later he built a circular track in London on which his locomotive pulling a wagon with passengers reached speeds of 16 kilometers per hour. Soon others realized that transportation by rail had a future and in 1820 several railroads were operating in industry. With George Stephenson (1781-1848), who built locomotives for these industrial lines, the railroads became also a serious competitor for the owners of coaches and canal track boats. In 1825 he opened the first railroad in the world that carried freight and passengers between Stockton and Darlington in northeast England. Five years later he participated in the establishment of another track between Manchester and Liverpool.

Until 1850 the expansion of the railroads was driven by industrial needs but they were spreading rapidly. In 1850 there were $10.715 \mathrm{~km}$ of railroad in Britain, $6.080 \mathrm{~km}$ in Germany, and $3.174 \mathrm{~km}$ in France. Transporting passengers turned out to be a very profitable business and railroad travelling soon became soon very popular (see Figure 15). The railroads drastically changed the world for many people. People who had never left their village could suddenly visit the big cities.

The railroads were vexed by safety problems and considerable efficiency

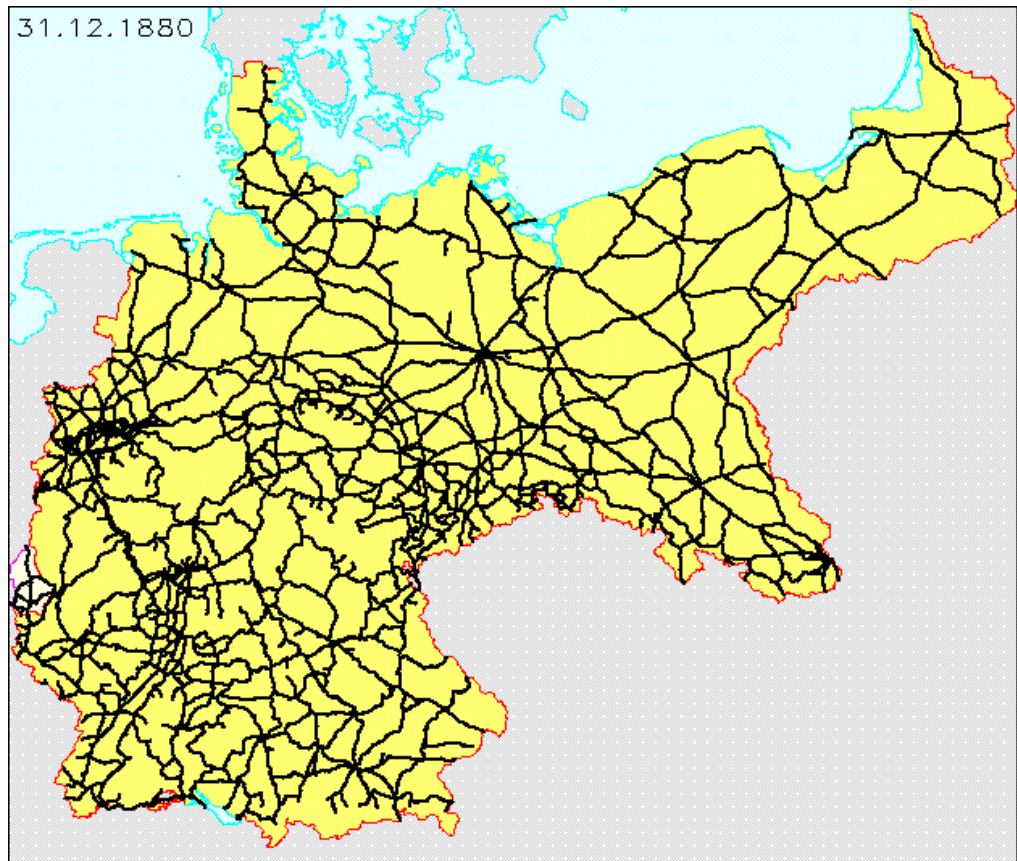

Figure 15. Railroad network in Germany in 1880. 
problems appeared. For example, in 1851 the Erie Railroad, (so-called so because it originally connected originally New York with Lake Erie), ran 123 locomotives, 68 passenger cars, and 1373 baggage and freight cars on 445 miles of track. They employed 1325 people. It turned out that the operating costs per mile increased with the growth of the railroad, contrary to the expectations. In 1856 Erie's superintendent, Daniel C. McCallum, created a new management system based on a tree like communication network. He introduced the multi-divisional structure. He divided his railroad into geographical parts of manageable size. Each division was headed by a superintendent responsible for the operations. The superintendents got reports from their subordinates and they submitted detailed reports to central headquarters where they were recorded and fields in statistical format. Data from different sources were compared in order to spot mistakes or dishonesty. The operations of the separate divisions were directed from the headquarters. McCallum's idea was to use the statistics to analyze traffic flow in order to avoid as much as possible unused capacity on return trips. The lines of authority in the hierarchy of the Erie railroad were clearly laid out. In sketching these lines on paper McCallum created possibly the first organizational chart for an American business. Soon the other railroads copied McCallum's system. The new chart required good communication. The first commercial electrical telegraph was patented in 1837 in England by Cooke and Wheatstone. It was the first to be used in commercial service. In the same period Morse built a telegraph system. In the 1840s along the railways the telegraph expanded rapidly.

There is an interesting precursor of the telegraph invented by Claude Chappe in 1792, a semaphore telegraph. It consisted of a network of relay towers, positioned at distances of 5 to 20 miles. At the towers the operators watched the neighboring towers with field glasses. On top of the towers was a cross bar and two indicator arms attached to it. By means of ropes and pulleys the operators could change the position of the bar and the arms and thus signal the letters, digits and other symbols. The system was used in several countries. After 1830 Chappe's semaphore network in France consisted of more than 500 towers. Its use was initially reserved for the French government. The idea to use such a system was much older. In 1684 Robert Hooke presented a system to the Royal Society based on the use of different subtended geometrical shapes by day and torches by night (see Figure 16 and Figure 17).

An interesting phenomenon was the atmospheric railway. Between the rails a partial vacuum in a traction tube makes a piston connected to the vehicle move. Several atmospheric railways were built and in the 1840 s it was a serious rival to the steam locomotive (see Figure 18). See, for example (Buchanan, 1992).

The inventor of the first practical telephone was Alexander Graham Bell. Bell made the first long distance call-over $16 \mathrm{~km}$-in 1876. The Hungarian engineer Tivadar Puskás invented the telephone exchange.

The telephone network grew quickly. At the end of 1904 in the US at least $3,317,000$ phones were connected (AT \& T, 2012). 


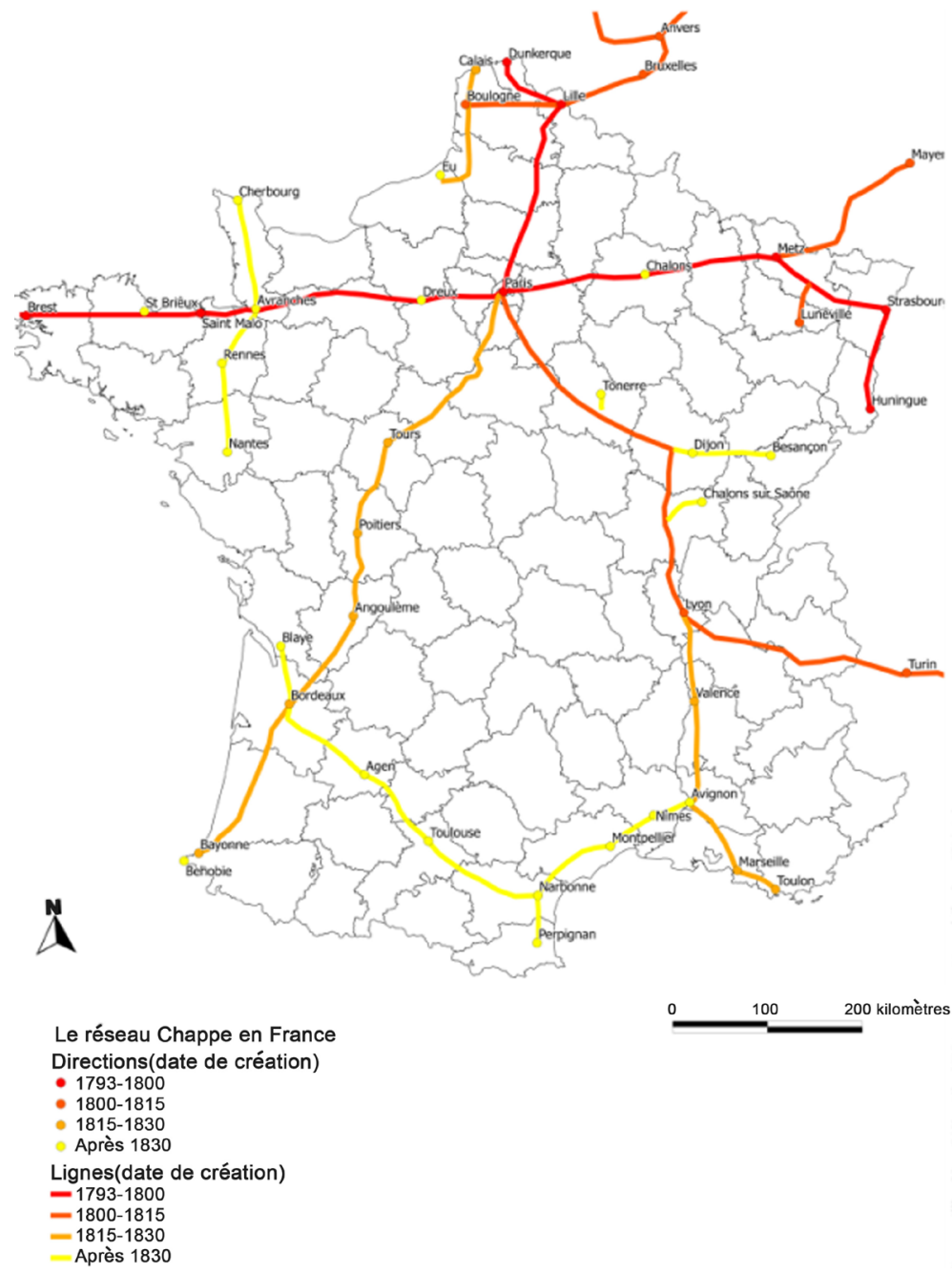

Figure 16. Chappe's semaphore network.

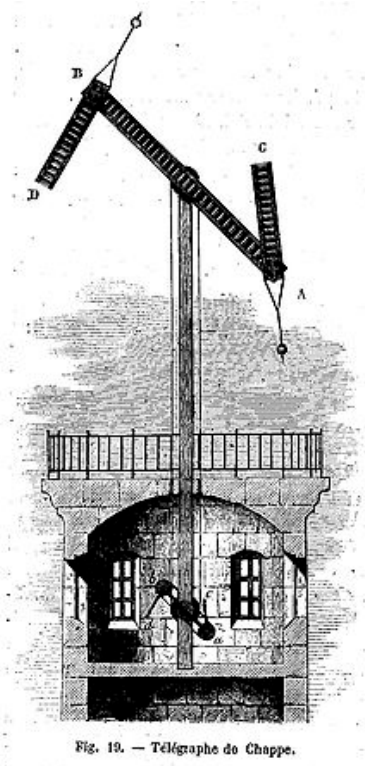

Figure 17. Signal tower. 


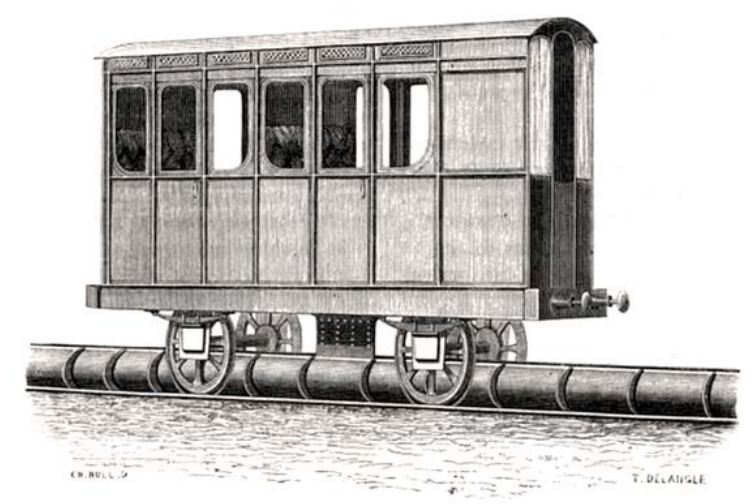

Figure 18. Leading vehicle of the French atmospheric railway from Paris to Saint-Germain.

In 1894-1895 Guglielmo Marconi invented the first radio transmitter and receiver that worked well. For the communication he used radiotelegraphy. Radiotelegraphy was intensively used for long distance communication until after the Second World War. In 1946 in the Unites States 212,977,622 telegrams were sent (Bureau, 1948). In 1967 the number had dropped to 77,401,406 telegrams sent (General, 1967).

After Thomas Edison invented a practical light bulb in 1879 he imagined introducing electric light in big parts of New York. From a steam driven generator electricity would be distributed through network to the customers. In 1882 he built the first generating plant on Pearl Street. Edison used direct current (DC). Because DC electricity weakens considerably in the distribution lines, the networks remained rather small. However soon the transmission of electricity over great distances became possible with the further development of alternating current (AC) technology. Powerful AC transformers designed by Nikola Tesla overcame the limitations of the DC technology. In the period from 1917 to 1927 the electrical output from utility companies exploded from 5.9 million $\mathrm{kWh}$ to 75.4 million kWh (Stevenson, 2018: p. 130).

Wireless transmission of the human voice started in the early 20th century. The Brazilian priest Roberto Landell de Moura seems to have been the first with a transmission in 1900. Television soon followed. In 1909 in Paris Georges Rignoux and A. Fournier successfully demonstrated the instantaneous transmission of images (Varigny, 1909: p. 451).

In 1950 there were is the USA $85,200,000$ radio receivers. Ten years later the number had doubled. In 1953 in the USA the number of TV receivers was 27,300,000 and in 1960 the number had doubled (Unesco, 1963). The number of telephone connections in 1960 in the USA was 49,269,000 and in that year $93,287,000,000$ conversations took place inside the US. Outside the US the number was 13,000,000 (General, 1960).

In the 18th century the Montgolfier brothers designed the hot-air balloon and began manned flights. Soon in France balloons were used for military purposes. In the early-20th century with the new developments in scientific technology powered flight became possible. Ferdinand von Zeppelin's airships dominated 
until the 1930. Then flying boats were popular for a while and finally the land planes took over. The first airline was founded in Germany in 1909. It used Zeppelin airships. The earliest fixed wing airline in Europe was Aircraft Transport and Travel, created in 1916. It is an ancestor of modern-day British Airways.

The Swiss mathematician Leonhard Euler (1707-1783) seems to have been the first to study the structure of a network mathematically. He gave a rigorous proof of the fact that a particular walk in the city of Köningsberg was impossible. The problem is called the problem of the seven bridges of Köningsberg. It is one of the first results in the branch of mathematics called graph theory.

\section{Towards the Internet}

ARPA was the predecessor of the Defense Advanced Research Projects Agency (DARPA) of the US Department of Defense for the development of new military technologies. In 1960 the head of ARPA's Information Processing Technique's Office, J.C.R. Licklider, wrote. "Any present-day large-scale computer is too fast and too costly for real-time cooperative thinking with one man. Clearly, for the sake of efficiency and economy, the computer must divide its time among many users". And he continued as follows: "It seems reasonable to envision, for a time 10 or 15 years hence, a 'thinking center' that will incorporate the functions of present-day libraries [...] The picture readily enlarges itself into a network of such centers, connected to one another by wide-band communication lines and to individual users by leased-wire services. In such a system, the speed of the computers would be balanced, and the cost of the gigantic memories and the sophisticated programs would be divided by the number of users".

The program to create such a network of computers became known as the ARPANET project. In the spring of 1971 ARPANET (Advanced Research Projects Agency Network) consisted of 23 computer systems-they were called hosts-working together. In that same year a mail system was developed for ARPANET and surprisingly the e-mail traffic turned out to be a huge success (see Figure 19). The success was so great that the demand for e-mail was outside ARPA one of the driving forces to create other computer networks.

The Internet appeared when computer networks started to be connected. However, it took many years before a significant number of networks would be connected. In 1984 the number of hosts on the internet was 1000. The connected networks were located in universities and research institutions. At the end of the 1980s most professional computer users had access to the Internet. And people started to send each other not only messages but documents.

\section{From the Internet of Things to GIM, the Global Intelligent Machine}

In 1999 Kevin Ashton made a presentation at Proctor \& Gamble in which he proposed the notion of the Internet of Things. Wikipedia defines the Internet of 


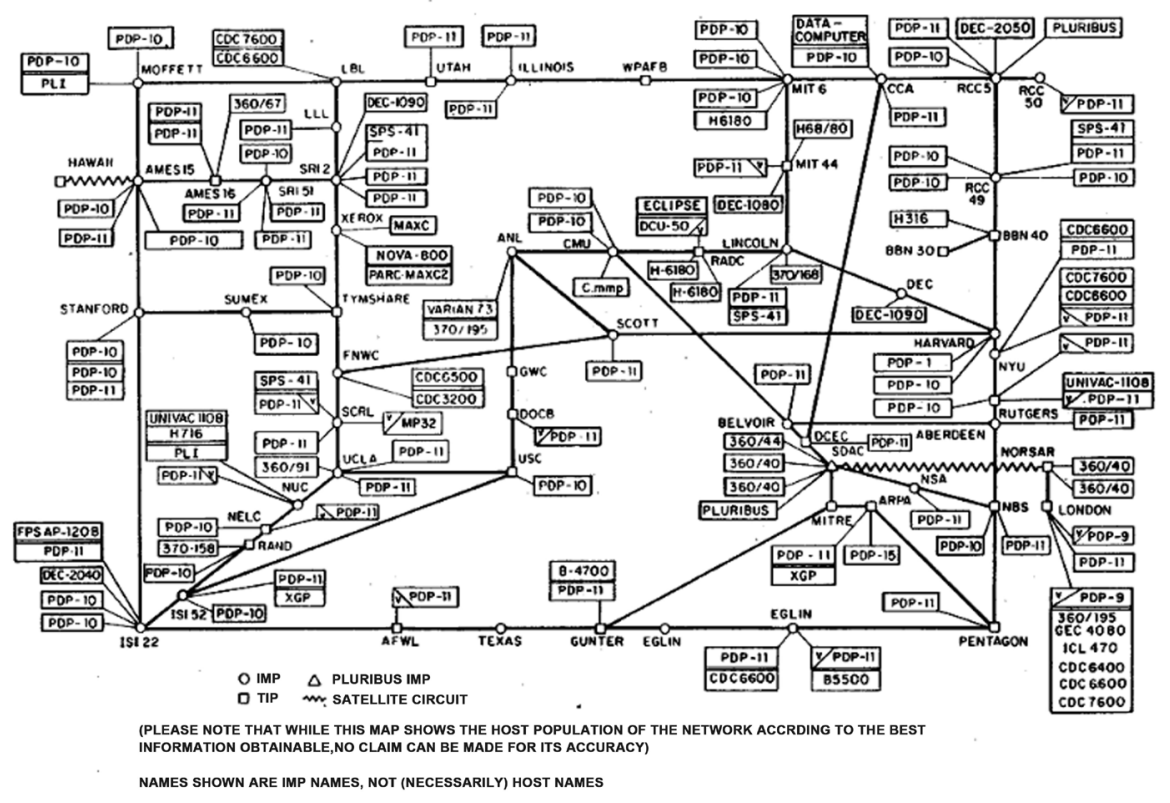

Figure 19. Network of Arpanet hosts in 1977.

Things as follows: "The Internet of Things (IoT) is the network of physical devices, vehicles, and other items embedded with electronics, software, sensors, actuators, and network connectivity which enable these objects to collect and exchange data". And "Experts estimate that the IoT will consist of about 30 billion objects by 2020 ".

The transition from the Internet to the IoT was only the first step and it seems inevitable that the IoT will be connected more and more to production devices. Until now the information gathered and processed by the IoT in general has led to a response in which machinery and human intervention are both involved. It seems inevitable that in the future we will often let machines autonomously do the work. The next step will be that the IoT will develop into what I call the Global Intelligent Machine (GIM). It not only gathers and processes autonomously enormous amounts of information but at the same time autonomously intervenes in nature all over the place.

The world has never seen such an entity before. Consisting of many parts it is definitely one entity. Its parts are connected and there are basic principles that determine the functioning of the whole. GIM is at heart a giant robotic machine. Much of its input comes from a complex system of sensors. Much of its output consists in a physical intervention in nature by means of a numerous robots. Moreover, it possesses brains in the form of very smart and very fast processing units. Apart from its global size the main difference with industrial, field and service robots is that the relation between input and output is not determined by one chief manager. GIM is not fully autonomous. Many different actors, individuals, companies, states, and other institutions or organizations control parts of GIM and use it for their own purposes. Some of these actors control substan- 
tial parts of GIM but none of them has complete control.

\section{More about GIM}

I am not the first one to realize that the Internet of Things is changing into something bigger and qualitatively different. In 2015/16 Bruce Schneier proposed the name World-Sized Web for what I call GIM. In 2018 he suggested the name Internet Plus (Schneier, 2018). Schneier and myself mean the same, but I prefer the name Global Intelligent Machine. Of course GIM's core is a world-sized web, but so are the Internet and the Internet of Things. GIM is in my opinion more than a web, it is a huge hybrid machine consisting of many information and production machines. It is getting more and more intelligent and it is global.

All communication networks that we met above can be considered as predecessors of the Internet, the IoT, and of GIM. Their modern versions are highly technologized and have become part of GIM. The same holds for the modern versions of the transportation networks that we discussed. It is not hard to find examples. Smart highways are the future. Smart vehicles fitted with sensors will communicate with the road. Many of these vehicles will become self-driving over the course of time. About $90 \%$ of international trade is done by sea. Many actors are seriously studying autonomous boats. In September 2017 Rolls Royce announced that they intend to build a naval vessel for patrol and surveillance and mine detection that can operate by itself for 100 days straight. Almost completely autonomous terminals in ports already exist, for example the RWG terminal in Rotterdam. A 2017 McKinsey report says about smart electricity grids: "Drones and insect-size robots identify defects, predict failures, and inspect assets without interrupting production". Irrigation systems will become smart as well. Smart controllers monitor soil conditions, the weather, and automatically adjust the watering schedule.

Wherever one looks the networks are getting smart and are becoming part of GIM, the Global Intelligent Machine.

GIM may seem like an entity from a science fiction film and indeed everybody working in artificial intelligence or robotics knows that many of the technologies involved need considerable improvement. Yet there are no good reasons to suppose that these improvements will not be realized. The self-driving car makes a fully automated transportation company possible. Engineers are dreaming about automated factories, farms, hotels, prisons, hospitals and what have you.

Most engineers specialize and concentrate on particular specific local problems. This is good; there would be no progress without specialization. Yet it is necessary that we study GIM from a holistic point of view. Schneier points at the many security issues that GIM confronts us with (Schneier, 2018). Another important is issue is the question of how far we want full automation to go. What is the role of man in a fully automated world?

\section{Conflicts of Interest}

The author declares no conflicts of interest regarding the publication of this paper. 


\section{References}

Allen, B. (1983). Human Geography of Papua New Guinea. Journal of Human Evolution, 12, 3-23. https://doi.org/10.1016/S0047-2484(83)80010-4

AT \& T (2012). History of AT\&T. https://web.archive.org/web/20120820015455/http:/www.corp.att.com/history/history1 $\underline{. \mathrm{html}}$

Blechman, A. D. (2007). Pigeons: The Fascinating Saga of the World's Most Revered and Reviled Bird. New York: Grove Press.

Blegen, N. (2017). The Earliest Long-Distance Obsidian Transport: Evidence from the $\sim 200$ ka Middle Stone Age Sibilo Road Site, Kenya. Journal of Human Evolution, 103, 1-19. https://doi.org/10.1016/j.jhevol.2016.11.002

Buchanan, R. A. (1992). The Atmospheric Railway of I. K. Brunel. Social Studies of Science, 22, 231-241. https://doi.org/10.1177/030631292022002003

Bureau de l'Union Internationale des Télécommunications (1948). Statistique Générale de la Télégraphie Année 1946.

http://search.itu.int/history/HistoryDigitalCollectionDocLibrary/6.78.69.fr.pdf

Carter, R. A. (2012). Watercraft. In D. T. Pots (Ed.), A Companion to Archeology in the Ancient near East (Vol I, pp. 347-354). New York: Wiley-Blackwell.

Dalley, S., \& Oleson, J. P. (2003). Sennacherib, Archimedes, and the Water Screw. Technology and Culture, 44, 1-26. https://doi.org/10.1353/tech.2003.0011

Edmund Lien, Y. (2015). Reconstructing the Postal Relay System of the Han Period. In A. Richter (Ed.), History of Chinese Letters and Epistolary Culture (pp. 15-52). Leiden: Brill.

Eliot, C. W. J. (1955). New Evidence for the Speed of the Roman Imperial Post. Phoenix, 9, 76-80. https://doi.org/10.2307/1086706

Gardner Wilkinson, J. (1854). A Popular Account of the Ancient Egyptians, Vol.2. London: John Murray.

General (1960). General Telephone Statistics fort the Year 1960. http://search.itu.int/history/HistoryDigitalCollectionDocLibrary/6.177.69.m7.pdf

General (1967). General Telegraph Statistics for the Year 1967. http://search.itu.int/history/HistoryDigitalCollectionDocLibrary/6.101.69.m7.pdf

Gosch, S. S., \& Stearns, P. N. (2008). Premodern Travel in World History. Milton Park: Taylor \& Francis.

Hayhurst, J. D. (1974). The Pneumatic Post of Paris. http://www.cix.co.uk/ mhayhurst/jdhayhurst/pneumatic/book1.html

Heide, M. (2010). The Domestication of the Camel: Biological, Archaeological and Inscriptional Evidence from Mesopotamia, Egypt, Israel and Arabia, and Literary Evidence from the Hebrew Bible. Ugarit-Forschungen, 42, 331-382.

Herodotus (1920). The Histories (with an English Translation by Godley, A.D., Book 4, Chapter 33, Sections 1 and 2). Cambridge: Harvard University Press. http://www.perseus.tufts.edu/hopper/text?doc=Perseus:text:1999.01.0126

Kellermann, R., \& Treue, W. (1962). Die Kulturgeschichte der Schraube. München: Verlag F. Bruckmann.

Koetsier, T. (2019). The Ascent of GIM, the Global Intelligent Machine, A History of Production and Information Machines. Berlin: Springer International Publishing. https://doi.org/10.1007/978-3-319-96547-5

Lovell, J. (2007). The Great Wall: China against the World, 1000 BC-AD 2000. Atlantic 
Books.

Meyers, R., \& Harris, M. (1990). Spreading the Word, the Distribution Networks of Print 1550-1850.

Millard, A. R. (1987). Cartography in the Ancient near East. In J. B. Harley, \& D. Woodward (Eds.), The History of Cartography (Vol. 1, Chapter 6). Chicago: University of Chicago.

https://www.press.uchicago.edu/books/HOC/HOC_V1/HOC_VOLUME1_chapter6.pd $\mathrm{f}$

Morris, I. (2010). Social Development. Stanford, CA: Stanford University.

Ober, J. (1985). Fortress Attica: Defense of the Athenian Land Frontier 404-322 B.C. Leiden: E. J. Brill.

Oleson, J. P. (1984). Greek and Roman Mechanical Water-Lifting Devices: The History of a Technology. Toronto, Buffalo London: University of Toronto Press.

Quilici, L. (2008). Land Transport, Part 1: Roads and Bridges. In J. P. Oleson (Ed.), The Oxford Handbook of Engineering and Technology in the Classical World (pp. 551-579). Oxford: Oxford University Press.

Schneier, B. (2018). Click Here to Kill Everybody: Security and Survival in a Hyper-Connected World. New York: W. W. Norton \& Company.

Seltman, C. T. (1928). The Offerings of the Hyperboreans. The Classical Quarterly, 22, 155-159. https://doi.org/10.1017/S000983880002961X

Stevenson, M. (2018). We Do Things Differently: The Outsiders Rebooting Our World.

Unesco (1963). Statistics on Radio and Television 1950-1960. Unesco Statistical Reports and Studies. http://unesdoc.unesco.org/images/0003/000337/033739eo.pdf

Varigny, H. (1909). La vision à distance. Paris: L'Illustration. http://histv.free.fr/rignoux/rignoux1909.htm

Wilson, A. I. (2008). Hydraulic Engineering and Water Supply. In J. P. Oleson (Ed.), The Oxford Handbook of Engineering and Technology in the Classical World (pp. 285-318). Oxford: Oxford University Press. 


\section{Source of Figures}

Figure 1: https://commons.wikimedia.org/w/index.php?curid=15886477

Figure 2:

https://en.wikipedia.org/wiki/Achaemenid_Empire\#/media/File:Illustrerad_Verl dshistoria_band_I_Ill_055.jpg

Figure 3: (Gardner Wilkinson, 1854: p. 4)

Figure 4: https://commons.wikimedia.org/wiki/File:Qanat-3.svg

Figure 5: https://en.wikipedia.org/wiki/Sakia

Figure 6: https://commons.wikimedia.org/wiki/File:Hama-3_norias.jpg

Figure 9: https://commons.wikimedia.org/w/index.php?curid=6308899

Figure 12:

https://commons.wikimedia.org/wiki/File:Press_skeen_1872_with_description.p ng

Figure 13: https://en.wikipedia.org/wiki/Friedrich_Koenig

Figure 14: http://www.cix.co.uk/ mhayhurst/jdhayhurst/pneumatic/book1.html

Figure 15: http://www.ieg-maps.uni-mainz.de/mapsp/mapebga0.htm

Figure 16: https://commons.wikimedia.org/wiki/File:Reseau_chappe77.png

Figure 17:

https://nl.wikipedia.org/wiki/Semafoor_(communicatie)\#/media/File:T\%C3\%A9

1\%C3\%A9graphe_Chappe_1.jpg

Figure 18:

https://commons.wikimedia.org/wiki/File:Wagon-directeur-chemin-atmospheri que.jpg 